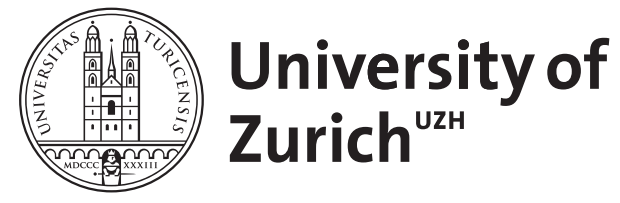

\title{
Democracy without Certainty : Derek Malone-France and the Virtue of Anxiety
}

\author{
Amesbury, Richard
}

\begin{abstract}
How anxious ought we to be made by a sober recognition of our own fallibility, and what are the implications of this fallibility for the use of political coercion? This article engages Derek Malone-France on the significance of anxiety for democracy.
\end{abstract}

DOI: https://doi.org/10.1179/1462317X14Z.000000000119

Posted at the Zurich Open Repository and Archive, University of Zurich

ZORA URL: https://doi.org/10.5167/uzh-120499

Journal Article

Accepted Version

Originally published at:

Amesbury, Richard (2015). Democracy without Certainty : Derek Malone-France and the Virtue of Anxiety. Political Theology:online.

DOI: https://doi.org/10.1179/1462317X14Z.000000000119 


\title{
Democracy without Certainty: Derek Malone-France and the Virtue of Anxiety \\ Published in Political Theology, 2015. Published version available at: http://www.maneyonline.com/doi/pdfplus/10.1179/1462317X14Z.000000000119
}

\author{
Richard Amesbury \\ Professor of Theological Ethics \\ University of Zurich \\ richard.amesbury@sozethik.uzh.ch
}

Recent decades have seen an explosion of literature on the relation between religion and liberal democracy, much of it inspired (positively or negatively) by Rawls, but Derek Malone-France's new book, Faith, Fallibility, and the Virtue of Anxiety: An Essay in Religion and Political Liberalism, moves this debate forward in potentially fruitful and completely novel ways by drawing attention to the epistemic and political significance of human finitude and fallibility. ${ }^{1}$ On Malone-France's account, anxiety -conceived as an epistemic (and also civic) virtue deliberately to be cultivated, rather than an existential "problem" to be lamented or suppressed -- constitutes a hitherto largely untapped resource for liberal political theorists, as well as for those seeking to forge an overlapping consensus among citizens subscribing to divergent comprehensive doctrines.

Malone-France's book is both intellectually challenging and beautifully written, and it ranks alongside Christopher Eberle's Religious Conviction in Liberal Politics (2002) and Jeffrey Stout's Democracy and Tradition (2004) as one of the finest, most important books of its kind. Like Stout's book, its scope includes, but extends well

\footnotetext{
${ }^{1}$ Derek Malone-France, Faith, Fallibility, and the Virtue of Anxiety: An Essay in Religion and Political Liberalism (New York: Palgrave Macmillan, 2012). Subsequent parenthetical references are to page numbers in this volume.
} 
beyond, the question of whether it is ever appropriate to rely on religious reasons in political decision-making. More fundamentally, Faith, Fallibility, and the Virtue of Anxiety is concerned with both philosophical and theological questions about what, following Kant, Malone-France calls transcendental anthropology, i.e., constitutive features of human existence as such. Stepping beyond any possible historical bifurcation between religious and liberal sensibilities, Malone-France finds in the universally shared condition of human finitude "the necessary bridge concept between authentic religious faith and Enlightenment liberal norms" (30).

I share many of Malone-France's concerns and find his argument here largely persuasive. Like Malone-France, I am a fallibilist (although I suppose I could be mistaken about that) with both theological and democratic convictions, which I like to think are not incompatible. I am not a process theologian and so will leave MaloneFrance's discussion of process thought (in Chapters 5 and 6 ) for others to address, but it is nevertheless from a place of broad agreement that I shall seek to engage his argument in the book's first four chapters.

How anxious ought we to be made by a sober recognition of our own fallibility, and what are the implications of this fallibility for the use of coercion? By offering somewhat different answers to these questions than the ones Malone-France provides, I hope both to highlight what I take to be original in his argument and to reveal certain weaknesses in its presentation.

\section{In Praise of Anxiety}


The core of the book's argument is that an appreciation of human finitude, particularly human fallibility, appropriately results in a stance of epistemic anxiety, which in turn supports an ethico-political norm of non-coercion. The sort of anxiety MaloneFrance has in mind is not pathological:

An underlying and permanent sense of epistemic anxiety among a democratic citizenry is a socially and politically healthy thing precisely because it serves to maintain citizens' acknowledgment of their own fallibility -- both as individuals and as members of religious and other groups -- and, thereby, discourages the sort of illegitimate absolutist and exclusivist attitudes that tend to undermine the reasonability and productivity of democratic discourses (29).

Anxiety, on his account, is also an authentic and appropriate religious response -- an anti-idolatrous recognition of our creatureliness. Malone-France sees this emphasis on the limits of human thinking as a useful corrective to the Kantian attempt to ground autonomy on the majesty of human reason. As Malone-France points out, the categorical imperative to treat others never simply as means but always as ends is consistent with coercion "if one believes that the individual's salvation -- be it political or spiritual -- depends on the acceptance of a set of beliefs and practices for the validity of which one claims absolute assurance" (14). But the virtue of anxiety blocks the attempt to circumvent the intent of Kant's claim for autonomy by insisting that absolute assurance is impossible. Because one might, in the event, be wrong about what someone else's salvation requires, one should refuse "to impose restrictions on the right 
of individuals to define the terms of their own lives, so long as their decisions cause no substantive harm to others" (37).

Consider the following example that Malone-France provides, which I shall quote in full:

Given the fallibility of any and all of our particularistic knowledge claims, we should have no greater moral fear than that we might impose on others a coercive norm that is, in fact, mistaken. The current debate in the United States over gay marriage provides a powerful and illuminating example of why this is so. Let us imagine, for the moment, that I am a traditionalist Christian who believes that the Bible reveals God's definitive judgment prohibiting homosexuality and establishes as a matter of transcendental anthropology that homosexuality is a freely chosen, rather than a biologically dictated, manner of life. And let us further imagine that I have worked diligently within the public sphere to help ensure that existing legal prohibitions against gay marriage remain in force, thereby maintaining what I view as a consonance between divine and human law. What if I am wrong? What if God did not intend for those statements in the Bible that repudiate homosexuality to become the basis for such a universal proscription? What if there is no God? What if homosexuality is not (or not purely) a choice but a matter of strong (maybe even definitive) biological inclination? Then I would have played a role in the irreparable mangling of other human lives. I would have prevented other, rightfully autonomous 
human beings from experiencing important elements of self-determination, fulfillment, and happiness. What could possibly give me the right to take that existential gamble on their behalf (88-9)?

The point Malone-France is making with this example is of course not limited to the issue of same-sex marriage: as he puts it in another place, "[g]iven the acknowledgment that it is, in principle, always possible that I am the one who is mistaken, even regarding my most deeply held beliefs, I cannot legitimately claim the right to coerce others to believe as I do" (or presumably to behave as I believe they should) (36).

Neither, as I read him, is the point limited to "religious" commitments: because fallibility encompasses the entirety of our beliefs, anxiety ought to leave nothing untouched. Although Malone-France seems often to have in mind situations where the convictions that inform one's political behavior belong to particularistic "worldviews" (see, e.g., 41), there is no obvious reason why the anxiety occasioned by human fallibility should be limited to these: one might, after all, be mistaken as well about scientific, mathematical, or historical facts; about what conclusions follow from one's premises; and so on. But just because fallibility applies globally, including in less controversial cases, I want to ask whether in fact it is really this that lies at the root of the discomfort generated in me by the example above and other examples of coercion Malone-France provides.

\section{Fallibilism versus Doubt}


It is important to appreciate that none of what Malone-France says about anxiety is meant to imply a general skepticism about claims to moral, religious, or political knowledge, nor is it meant to suggest that all positions on a given issue are equally reasonable $(16,36)$. Nevertheless, Malone-France suggests, "there will always be a range of reasonable alternatives in relation to any issue of metaphysical, moral, or political significance" (36). When confronted with reasonable alternatives to our own convictions, we have every right to argue, and to attempt to persuade, "[b]ut we cannot arrogate to ourselves the right to coerce (at least not outside of the legitimately negotiated coercive requirements of democratic decision-making procedures)" (37).

I will return to Malone-France's exception for democratically mediated coercion in a moment. First, however, I want to consider the question of whether fallibility as such -considered as a feature of the human condition, distinguishable from specific reasons for doubting specific claims -- is sufficient to warrant the conclusion at which MaloneFrance arrives. Is, in other words, the mere possibility that I could be wrong, absent positive reasons for thinking that I actually am, a good reason, as he suggests, for me to refrain from coercing others no matter the issue at stake? My worry is that at crucial points in the development of Malone-France's argument, a stronger sort of doubt seems to creep in by means of examples that engage readers' existing (rationally defensible) convictions. For instance, Malone-France's example about same-sex marriage surely derives some of its force from the fact that many of his readers are likely to take ourselves to have good reasons to doubt the correctness of this imagined activist's beliefs. But notice: good reasons. Our worry is not about the possibility of his being 
wrong -- his fallibility -- but about its actuality. (Less tendentiously: it is the substance of the view that worries me.)

Although Malone-France's argument is officially framed in terms of fallibilism as such -- i.e., "the acknowledgment that it is, in principle, always possible that I am the one who is mistaken" (36) -- it is helped along, I would suggest, by examples that implicitly elicit not merely Socratic anxiety, but stronger, more positive doubts on the part of sympathetic readers. A moment ago I quoted Malone-France's remark that "there will always be a range of reasonable alternatives in relation to any issue of metaphysical, moral, or political significance" (36). I am not sure whether I would personally go as far as to say that there will always be reasonable alternatives, although certainly there is a range of reasonable alternatives about many issues, such as the ones that remain unsettled in the larger culture. But even as it stands, Malone-France's formulation suggests, rightly in my view, that there might be alternatives that fall outside the range of what is reasonable. Some of the examples Malone-France supplies to illustrate the importance of a generalized epistemic anxiety -- including Nazism, slavery, and the authoritarian excesses of Calvin's Geneva -- arguably belong (at least for his readers) in this latter category. That they are not live options (and indeed are paradigmatically abhorrent ones) facilitates the argument's seemingly direct move from fallibility to non-coercion: none of us wants to be coerced into adopting those options. The tougher sell would be convincing readers that they ought not to "impose" views they themselves think are actually true, but which are nevertheless not universally shared, such as that the climate is changing largely as a result of human activity, or that people 
are more likely to get shot when guns are widely available. If fallibility is held to rule out coercion, it rules it out not merely when it arises from false premises, but also when the premises are true.

\section{Autonomy and the Virtue of Tolerance}

That fallibility is not, all by itself, a sufficient reason to refrain from coercion is, however, suggested by Malone-France's exemption, noted a moment ago (see too 64), of coercion that is vetted by discursive, democratic decision-making procedures. If fallibility were really a reason to abstain from coercion, as seems to be suggested in Chapters 1 and 2, it is unclear why the democratic process should offer a route around this norm, since as Malone-France rightly notes in Chapter 4, "the procedural coordination of the deliberations of multiple fallible subjects does not somehow magically produce an infallible result" (81). On Malone-France's account, unlike for Habermas, say, redeemability in discourse merely points to and does not constitute the truth of a validity claim. ${ }^{2}$ Because democratic, discursive procedures do not remove such claims from the realm of human fallibility, the fact that, on Malone-France's telling, (some of) these claims apparently can legitimately be enforced suggests that fallibility is better conceived not as a bar to coercion tout court (though it clearly counsels a certain

\footnotetext{
${ }^{2}$ Whereas, in his early work, Habermas had argued that the validity of both claims to truth and claims to rightness depends upon their redeemability in discourse, his view has shifted. On his more recent account, both kinds of claims require discursive redemption, but the relation between validity and redeemability is different in theoretical cases than it is in moral ones. He writes, "Whereas rational acceptability merely points to the truth of assertoric propositions, it makes a constructive contribution to the validity of moral norms." Jürgen Habermas, The Inclusion of the Other: Studies in Political Theory, ed. Ciaran Cronin and Pablo De Greiff, trans. Ciaran Cronin (Cambridge: The MIT Press, 1998), 38. For a discussion and criticism of Habermas's distinction, see my Morality and Social Criticism: The Force of Reasons in Discursive Practice (New York: Palgrave, 2005), Chapter 2.
} 
wariness about it), but as a prompt to deliberation and procedural justice. While we cannot rise above fallibility, we can, through discourse, minimize our chances of being mistaken.

Deliberation is critically important, but when all is said, something must be done: a decision must be made, which will invariable result in winners as well as losers. As Rawls rightly observed, "[p]olitical power is always coercive power." Whether in extreme cases, like war-time drafts, or quotidian ones, like speed limits, compliance with law is achieved partly (albeit not exclusively) through force or its threat. The question for Rawls is consequently not whether coercion is licit, but under what conditions. It is illicit, on his account, when it is employed without proper respect for one's fellow citizens as free and equal, capable of framing, revising, and acting in accordance with their own conceptions of the good. In particular, this, for Rawls, means that when it comes to constitutional essentials and matters of basic justice, the reasons that motivate political action should be public. Though largely in agreement on the desirability of public reasons, Malone-France's argument can be understood as shifting the philosophical grounds from which this demand arises -- from a Rawlsian/Kantian focus on the question of the respect one owes to other citizens/persons to a deeper appreciation of the implications of one's own fallibility. This corresponds with a shift from tolerance, a moral-political virtue, to anxiety, an epistemic one (29). Whereas tolerance implies a judgment that the other is in error, anxiety directs critical scrutiny to one's own cherished commitments.

\footnotetext{
${ }^{3}$ John Rawls, Political Liberalism, Expanded Ed. (New York: Columbia University Press, 2005 [1993]), 68, italics added.
} 
But I wonder if the epistemic approach, notwithstanding its many merits, is fully satisfying in this regard. It seems to reduce autonomy to a merely negative value: it is good that others should have the ability to make their own decisions, because I should minimize my chances of damaging other people's lives by not presuming to impose my own fallible judgments on anyone other than myself. Their freedom is, so to speak, a byproduct of my incompetence and anxiety. The implication seems to be that if, per impossibile, I could be assured of forming correct opinions about moral, religious, and political matters, then I would have no reason not to coerce others into abiding by them. Malone-France says as much at one point: "only if I could infallibly know that I were right could I (perhaps) legitimately override the autonomy of another human being for my own purposes" (64). But the hesitant, parenthetical "perhaps" seems to suggest a nagging dissatisfaction with this view. The more "liberal" idea, after all, is that people should be free, within limits, to form false opinions and to make bad decisions. (Hence, I would argue, the continued need for tolerance: it is not because I hold open the possibility of their being right that I am willing to put up with people who believe that Barack Obama is a Kenyan-born Muslim socialist.)

\section{Secrecy and Coercion}

Still, whatever its limits, it seems to me that Malone-France is correct to identify fallibility as a crucial ingredient in both religious and liberal thinking, without which existing political theoretical accounts remain impoverished. And just as Rawls's emphasis on respect prompted fruitful debate about what exactly respect requires, so, I 
would hope, Malone-France's book will lead to further discussion of what anxiety requires. Although Malone-France often argues directly from fallibility to non-coercion, my sense is that what he really seeks to oppose is not coercion per se, but coercion grounded in secrecy and claims to infallibility. It is the latter, not necessarily the former, that is incompatible with fallibilistic anxiety.

In Chapter 3 Malone-France offers a powerful reading of Fear and Trembling, which follows Kierkegaard (or Silentio, his pseudonym) in seeing the story of Abraham's "binding" of Isaac as dramatizing the tension between, on the one hand, modern ethics' emphasis on the transparency and publicity of reasoning, particularly when that reasoning leads to action that affects others, and, on the other hand, a traditional emphasis, within Christianity and other religions, on private revelations and secrecy. As he explains the latter point, "No one who does not share directly in the revelation can be made to understand its force; it is inexplicable in abstraction from the concrete subjectivity of its experiential reception as an absolute determiner of belief and commitment" (60). Abraham is bound by a special, unique covenant with God, the demands of which are depicted by Silentio as directly in conflict with the universal demands of a publicly accessible morality.

Though the reasons behind his action are opaque to everyone other than himself -- or rather, precisely because of this -- Abraham is said to illustrate the heroic virtues of the "knight of faith," who obeys God even when called to act in ways that no one else can understand or approve of. By answering only to God, Abraham, on Silentio's telling, exercises "radical responsibility" for Isaac. But Malone-France departs from Silentio 
insofar as he thinks we should see nothing admirable in Abraham's actions. In appealing finally to a private revelation that cannot be communicated to or validated by others, the so-called "knight of faith" places undue confidence in his or her own capacity to have correctly understood the demands of faith.

Malone-France links Abraham's silence -- his refusal or inability to explain himself -- to what he sees as the "delusional certitude" characteristic of the $9 / 11$ hijackers, as well as to the "ongoing controversy in the United States over the expansion of the realm of state secrecy under the banner of the "war on terror"' $(65,72)$. Since the book was published, his reflections have taken on added urgency in light of, inter alia, our current president's secret "kill list"; the leaked Department of Justice memo justifying extra-judicial killings of American citizens; and the surveillance programs disclosed by Edward Snowden. Such examples collectively illustrate how, as Malone-France puts it, 'the 'heroic' conception of Silentian radical responsibility, once accepted at a religious level, inevitably invades the realm of political life, with tragic and oppressive results" (73). Operating on the basis of privileged certitudes that cannot be redeemed publicly, whether in the form of private religious revelations or classified intelligence, these various figures -- would-be sovereigns, in a Schmittian sense, teleologically suspending the ethical or legal order -- may suppress but do not succeed in removing the anxiety that ought to attend our finitude.

An appreciation of my own fallibility -- the fact that I am not God -- should give me pause, Malone-France thinks, when I am tempted to act, on the basis of what I take to be a revealed truth, in ways that affect others. He writes, "I believe this analysis of the 
essentially noncommunicative nature of such claims provides the missing framework needed to validate the Rawlsian argument that, as a general rule, religious reasons cannot be accepted by autonomous individuals as the basis for coercive regulations" (61).

\section{Democracy as Politics without Certainty}

To make certainty the only valid basis for coercion is, I have suggested, to set the bar too high -- beyond what even the democratic process could deliver. If, as Rawls notes, coercion is an ineliminable feature of politics, we would seem to require standards for its just deployment within the realm of fallibility. Coercion under democratic conditions is licit not when it has cleared the hurdle of human finitude, but when it is undertaken in accordance with fair and public procedures, with due respect for the autonomy of other selves. On this point I believe Malone-France and I are really in complete agreement. Indeed, to forbid political coercion because of fallibility seems, ironically, to involve precisely the sort of craving for final certainty that Malone-France convincingly argues we should try to overcome. Perhaps politics is inherently, not merely contingently, tragic, as a result precisely of human finitude, but just as, on Malone-France's account, we should not attempt to "solve" the problem of anxiety by appeal to some putative certainty, so, it might be argued, we should acknowledge that, within the realm of politics, coercion cannot be dissolved into persuasion, or decision into discourse, without remainder. "Inquiry, like life, must proceed in the absence of final 
certainty," Malone-France writes, and so too, we might add, must democratic politics (39). 